BOGDAN GULYAMOV,

National Pedagogical Dragomanov University (Kyiv, Ukraine)

e-mail: b.s.gulyamov1970@gmail.com,ORCID 0000-0001-8523-5420

\title{
SOCIAL DOCTRINE OF THE ECUMENICAL PATRIARCHATE ABOUT THE FAMILY
}

\begin{abstract}
The theory of family is at the heart of classic Christian social doctrine, since family exemplifies every sociality such as an ecclesial community, a work collective, a local community, a nation, humanity. Modern family crisis leads to the transformation of the social teaching when interpersonal relations become an example. In particular, relations between a husband and a wife in a family, relations between a person and God, relations within a monastic community, relations within an ecclesial Eucharistic community become a general ideal proposed for the secular sociality. In the ethics of family life, the social teaching of Constantinopolitan Patriarchate places special emphasis on the absolute dignity of the individual from the moment of conception to natural death. Large attention is paid to the protection of children from various menaces in the society, effective measures are suggested in order to avoid the crimes against children. The apology of all aspects of sexual life of a family is also provided, various biases with regard to women and marriage are condemned. Generally, the social teaching of Constantinopolitan Patriarchate on a family is the expression of ethics of Christian realism where the recognition of the absoluteness of certain values is joined with the readiness to understand and forgive human errors. In the doctrine of the family, social doctrine from the standpoint of communitarianism passes to the adoption of the principles of Christian personalism.
\end{abstract}

Key words: social teaching; Orthodox background; Christian personalism; theology of love.

\section{Introduction}

Thorough understanding of a family subject has the special significance for the social teachings of the Ecumenical Patriarchate. From the very beginning of the active development of social doctrine of the church in Christianity at the end of 19th century, the subject of family life assumes paramount importance. Firstly, the Popes, starting with Leo $\mathrm{X}$, particularly emphasized the meaning of a family as a small society being the basis for all greater social relations. Of course, these speculations about the family even then departed from the Aristotelian understanding of the state as a large family. However, the analogy between the family and the whole large society was considered fruitful, since it is more naturally and easier to accept the social duties in a family and then these duties may be transferred to all social relations. Secondly, the family was thought to be a small society, starting with the recovery of which you can achieve the health of the whole society. Overcoming a number of social ills such as alcoholism, poverty, lack of solidarity was thought of as possible starting from the bottom, from the level of the individual family. Some excessive fascination with the ideas of organic development of an individual within the large family of society began to decline in the middle of the 20th century. A separate personality, his/her dignity and rights became fundamental principles for secular and religious moral and legal cultures. Under such conditions, the family became understood as a space for special interpersonal relations. Gradually, the teaching about the special holiness of family life is formed within the framework of the doctrines of Western churches. Family life is understood as a main Christian mission that imposes special responsibilities on him or her. On this ground, the marriage ideal is often brought up so high that the contradiction with the idea of human rights arises. Under such conditions, protestants of the West often choose realism and relations built in various periods of life of a person are blessed. Catholicism and some Protestant fundamentalists continue to emphasize the possibility of only one marriage. Under such conditions, a lot of pastoral issues appear for Orthodox Christians to be answered by social doctrine and the teaching of the church as a whole. Also, the question of assessing the lives of single people, who are a very significant group in some developed countries, even among Christians, is becoming increasingly important. Marriages between Christians of different denominations and with representatives of different religions are becoming more common. Also, more and more theological theories are emerging about the nature of sexuality. The social teaching of the church is designed to provide answers both to questions of a more theoretical nature and to provide clear guidelines for pastoral practice. The document of the AllOrthodox Council of 2016 "The sacrament of marriage and obstacles to it" did not address a number of voiced issues. That is why those sections of the document "For the Life of the World. Toward a Social Ethos of the Orthodox Church" (Greek Orthodox..., 2020), which concern the ethics of family relations and the Orthodox doctrine of the family.

The purpose of the article is the analysis of the main features of the social teaching of the Ecumenical Patriarchate about families. 


\section{Research methods}

The hermeneutic method was used to analyze the documents expressing the social teaching of the Constantinopolitan Patriarchate. To explain the nature of this social teaching, the comparative analysis was used as well as the religious and theological analysis of the evolution of the basic ideas of Christian social teaching. Broad theological discussions are just starting around the document "For the Life of the World". External reviewers also only delve into the reception of this document in the Orthodox Church, highlighting only elements of some liberalism compared to similar Orthodox social teachings of other local churches (Chryssavgis, Hollander, 2020; Frost, 2020; Bishop, Chryssavgis, 2020; Gallaher, Dorroll, 2020; Frost, Mamalakis, 2020; Kazarian, Kitanovic, 2021; Demacopoulos, Johnson, 2020; Woloschak, Patitsas, 2020; Papanikolaou, Hanegraaff, 2020; Fr. Hamalis, Harper, 2020). At the same time, the document "For the Life of the World" provides general principles for the modern Orthodox understanding of a family, thereby the ideas stated in it need more detailed analysis (Frost, Mamalakis, 2020).

\section{Results and Discussion}

Actually, a separate section of the declaration "For the Life of the World" is devoted to the theory of life in the family, which is called "The Course of Human Life". Within this section, a holistic overview of everything related to the life of the individual, his or her physicality, his or her relationships within the family and the immediate environment. Thus, the ethics of family life becomes a part of the ethics of a personal course of human life. This is because the dignity of the individual is a more important and fundamental principle and value than the value of the family. Even if a person does not create a family, he or she has an individual endless value. Thus, personalism is more important principle that the communitarianism, and a personality has value before becomes a social being. Social doctrine emphasizes that the personality has an absolute value from the conception to physical death $\left(F L W^{1}\right.$ : art.16). This absolute dignity requires from everyone the reverence for each person as the image of God (FLW: art.17). The most important temptation of today has been the humiliation of human value, the reduction of its value to the benefit that man has for society or, even more narrowly, for the global market. Emphasizing that the value of the individual cannot be reduced to benefit or questioned at all, the Orthodox Church stands for Christian humanism and pastoral prudence, offering a holistic view of possible positive scenarios for human life from conception to physical death, arguing that the various paths of the personal development are equally rooted in human nature, are largely equivalent to humanity and God (FLW: art.16-31).

The declaration attaches great importance to the protection of childhood. Children, including the unborn children, are extremely vulnerable to violence and need special care. The Declaration emphasizes that "a child's claim upon our moral regard then is absolute from that first moment, and Christians are forbidden from shedding innocent blood at every stage of human development" (FLW: art. 25). The declaration mentions that in the days of the Roman Empire, when human status depended on

${ }^{1}$ FLW: For the Life of the World. Toward a Social Ethos of the Orthodox Church. Declaration. the peculiarities of his or her socialization and newborns could be left to die, Christianity strongly opposed abortion, the practice of killing newborns. Alongside the protest against the death penalty, it became one of the distinguishing features of the Christian worldview for the whole world at that time. The Orthodox Church emphasizes that it is understanding about the fact of insuperable circumstance of life which sometimes cause the inevitability of abortion. However generally, the Orthodox teaching emphasizes the absolute value of a human person from the moment of his or her conception to the moment of natural death. The traditional teaching of the personal nature of the fetus and its right to life is the most controversial. The Declaration emphasizes the biblical roots of the teaching of the full personality of man during his stay in the womb. "Orthodox tradition, on the Feast of the Annunciation, celebrates the conception of Christ in his mother's womb, and on the Feast of the Visitation recalls John the Baptist leaping with joy in his mother's womb at the sound of the voice of the pregnant Mother of God. Already in the womb each of us is a spiritual creature, a person formed in God's image and created to rejoice in God's presence" (FLW: art. 25). The doctrine of the incarnation of God also allows for a respectful attitude to motherhood, to the fetus as a person. According to the metaphysics of Greek patristic, man is a person who arises instantly, not only as a personalized psychic being, but also as a personalization of bodily nature. Of course, there were some holy fathers in the tradition who attributed the animation of the fetus to 40 days from conception, but most emphasized the existence of the individual as the personal soul embodied in the fetus from the very first moment of conception. This vision was due to reverence for the gift of life, the inability to separate "pre-human" existence from the actual human in the history of each individual. "A human being is more than the gradually emergent result of a physical process; life begins at the moment of conception" (FLW: art. 25). A human being is the here and now existence which is thought as such that differs over those elements that make up this existence. The creation of the human personality does not prevent it from being an existence that is constantly directed towards transcendence to God from the moment of conception. The fetus is already an existence that feels God and experiences His intimacy no less intensely than a fully socialized personality, which has developed all its natural skills, including thinking and living in virtues. The respect to the human dignity of a fetus is possible because the purpose and the completeness of life for a personality is not the comprehensive development of its intelligence and other natural features, but deification (FLW: art. 15). Being in the presence of God, the maximum of which is deification, is possible for all people, regardless of the degree of development of their intelligence and other qualities. This changes the perspective of assessment. But a person who is disabled for ordinary secular assessments is not for a religious perspective. A disabled person or an unborn child may well have their own mystical connection with God, for which the Orthodox tradition can provide numerous testimonies. Indeed, if the main feature of humanism and personality is the ability to communicate with God and other people, and not intelligence, then it is no longer possible to look for reasons to exclude someone from the number of full-fledged people worthy of respect. The more unacceptable are rejections of 
humanity based on racial or ethnic biases which took place in the part when various pseudoscientific and pseudoreligious theories has significant influence. Today, the social teaching of the Ecumenical Patriarchate radically condemns any attempt to degrade human dignity, and criticizes not only such manifestations of social atavism as racism, but also modern theories that justify the instrumental attitude to human life depending on its usefulness to society, intelligence, ability to activity, etc. The reverence for the mystery of life is an important element of the Orthodox ethos which should be not only the theoretical domain of worldview but should be manifested practically. The declaration states that the Orthodox Church is always ready to come to the rescue to young mothers to save their children. "Church must be ready at all times - inasmuch as it truly wishes to affirm the goodness of every life - to come to the aid of women in situations of unintended pregnancy, whether as the result of rape or of consensual sexual union, and to come also to the aid of expectant mothers suffering from penury, abuse, or other adverse conditions, by providing them material and emotional support, spiritual succor, and every assurance of God's love, both during and after pregnancy" (FLW: art. 25). Such demand is a direct consequence of the liability for own views. Of course, today not all local churches and not all Orthodox communities in the whole world are ready for the responsible practical humanism in their attitude to women, not all are ready to treat with full respect the choice of everyone independent of his or her life circumstances, worldview and practical choices. But in general, such a statement requires a significant development of social service in the Orthodox Churches. While communities are not always able to meet their own needs, implementing such projects to help women in need should be a common goal for entire local churches. The creation of appropriate funds, charitable communities requires a system of spiritual care. One of the essential tasks should be to avoid any humiliation of young mothers or their children, as such phenomena have existed in such shelters in the past in different countries, even the most developed ones. Unfortunately, the declaration does not explicitly mention the right of all children to a family. Meanwhile, the adoption of orphans, including those born to women who have been persuaded to have abortions, is a significant social problem. And it is religiously motivated families that can radically change the adoption situation in each country. The declaration mentions these problems cursorily only twice. The list of measures to protect children from the greatest threats states the following: "The Church is called also to strive for the protection of children around the globe who are even in an era in which childhood mortality and disease are in decline globally - still subject in many places to war, enslavement, destitution, child labor, and (in the special case of young girls) arranged marriages, often as child brides. So long as these conditions persist in any part of the world, the Church cannot rest in its efforts to end them, by appeal to government authorities, by charitable aid, by assistance in systems of adoption, and by advocacy on behalf of these little ones" (FLW: art. 16). Here we do not see the proclamation of the clear principle that all children must have a family but the call itself to cooperate with adoption systems is positive for the social doctrine. Also in the list of God's blessings for the family, in addition to children born in wedlock, adopted are mentioned (FLW: art. 23). In general, it can be concluded that from the proclamation of the principle of the absolute value of the child and even the human fetus, numerous conclusions are drawn for social teaching, but many of them can still be expanded.

Separately, the declaration "For the Life of the World" emphasizes the need to protect children from sexual violence. This subject became acutely challenging over the last years, and the declaration states clear position with regard to the impossibility to conceal such crimes anyhow. "Sins against the innocence of children are sins of an especially loathsome kind. No offense against God is worse than is the sexual abuse of children, and none more intolerable to the conscience of the Church. All members of Christ's body are charged with the protection of the young against such violation and there is no situation in which a member of the Church, on learning of any case of the sexual abuse of a child, may fail immediately to report it to the civil authorities and to the local bishop. Moreover, every faithful Christian is no less bound to expose those who would conceal such crimes from public knowledge or shield them from legal punishment. Neither should any priest ever grant absolution to the perpetrator of such a crime until the latter has surrendered himself or herself to criminal prosecution" (FLW: art. 16). These principles are important because 20 years ago, there was a general culture of concealment of such crimes, especially if they were committed by priests or orphanages. The proclamation of the complete rejection of the practice of concealing such crimes is important in confirming the seriousness of the church's intentions to fight for the rights of children. The duty not to keep silence is directly proclaimed in the text of the declaration as an imperative to the direct action. There is only a difficult case with a priest who learns about a crime in confession: he has no right to violate the secrecy of confession, but may demand that the confessor be opened to the judiciary. The formation of more specific norms on the actions of believers, the priesthood, the episcopate in the event of such crimes is a matter of the future. But the general principles of the duty to protect children from sexual violence are well written and need to be promoted among Orthodox Christians. These principles correspond to the spirit of the Christian ethics and social doctrine: the general requirement of absolute respect for the dignity of the individual from the moment of his or her conception to natural death has its concretization here. Also in the formation of these principles an important role is played by the ability to put oneself in the place of a victim of crime. Empathy for victims is an important component of a culture without which humanity and civilization themselves experience a radical crisis. Of course, such empathy must be counted on in the Christian environment as an obvious ideological requirement. All cases where Christians did not stand on their own two feet today undermine the authority of Christianity in the world, and the Orthodox Church resolutely takes the place of the victims, demanding absolute respect for them regardless of all the circumstances in which crimes may have been committed. Reverence for the mystery of personal life, for the fullness of life, including the bodily life, must be returned to the center of the Christian worldview.

The declaration emphasizes that the Orthodox Church blesses various ways of life, especially married life. The document "For the Life of the World" states a fact that is 
usually ignored. Deification in Scripture is constantly likened to marriage. The declaration emphasizes that this is not an incident but a natural phenomenon. Although medieval culture elevated monasticism, in reality it was marriage that was of absolute importance. "There has been at many times in the history of the Church something of a tension between the married life and monasticism, at least as regards their relative spiritual merits. In large part, this was the result of an earlier, preChristian understanding of marriage; it was also the result, however, of the unfortunate reality that, until fairly recently in Eastern Christian tradition, spiritual teachings on these matters have been advanced principally by celibate men with no experience of the married life. It is time to put these pernicious prejudices aside and to recognize that marriage is much more than a cultural institution or merely a means for propagating and preserving the human race. If that were all that it is, scripture would not use nuptial imagery as the principal means of describing the sacramental and eschatological union of Christ and his Church. According to scripture, Christ vouchsafed his followers the first of his ministry's signs of divinity at the Wedding Feast in Cana. By contrast, the celibate life appears in the New Testament as having at most a practical value" (FLW: art. 20). It should be noted that the rise of celibacy to the heights of the main Christian ideal in the past was caused not only by the fact that confessors and elders were mostly monks who set a certain cultural trend. The very orientation of Orthodoxy to deification and communion with God has already provoked the formation of a tendency in monasticism to see a higher path of spiritual development and Christian life. Marriage under such conditions was thought of as something acceptable, but in principle lower. The statements of some ancient fathers on this subject contributed to the consolidation of the cult of celibacy. Thus, Gregory of Nyssa believed that in paradise for man was defined a higher, "angelic way" of reproduction, which would not involve sex as an animal way of mating. Researchers usually see in these ideas the influence of late Hellenistic philosophy schools and religious cults. Thus, the founder of Neoplatonism, Plotinus, was ashamed of his own body, not just wanted to part with it faster and be in an ideal spiritual world, but disgusted with all the corporeal. Similar psychological phenomena of aversion to corporeality were not only a special manifestation of spiritualism, but also a deep experience of dualism between soul and body. Christianity recognizes the existence of the mental and the corporeal as the two main aspects of human existence, but denies the existence of a fundamental difference between them. For non-Christian philosophical and religious teachings of late antiquity, the spiritual (incorporeal) was almost automatically "divine", belonged to the only eternal substance of all that exists. For Christian dogmatics it is principal to differentiate between the uncreated by eternal God and everything created, both material or spiritual. It is here that there is an "abyss" of distinction, while the distinction between the ideal and the material is only relative. Also, for all the distinction between the uncreated by God and the created everything else, the spiritual and the material are not entirely alien to God: they exist in communion with Him. The Christian God does not loathe the material, but loves it. The discovery of the biblical doctrine of the importance of the material and the corporeal became one of the important achievements of theology of the twentieth century. In Orthodox theological thought, it began with the realization of a fairly simple fact: the material must also be deified. Careful reading of such mystical treatises of tradition as "Triads in defense of the Hesychasts" by St. Gregory Palamas led theologians to the discovery that the holy fathers emphasized that God in mystical communion is known not only by contemplation of the soul, but also by the eyes of the body: either mental or bodily capabilities of a human equally rise to the height commonly unattainable for them and look at endless and transcendent being of God.

It is obvious that the emphasis on the sanctity of marriage came to the fore in the social teaching of the church when divorce and the choice of a solitary way of life began to spread. While family life was strongly motivated by tradition, the emphasis was on the importance of the vocation to monastic life as particularly important. Note also that from the beginning of the development of social doctrine, the family has been a model of sociality for the Eucharistic community, local communities, professional groups, various communities of interest, nations, humanity as a whole and so on. In the social teaching of the church, all humanity was a network of communities similar to families. However, if a family as an institute is in a determining crisis, then the vision of all other institutions also becomes doubtful. The apology of the family as a holistic way of life presupposes a less idealistic view of monasticism than that which prevailed in tradition and a sharp demarcation from attempts to at least to some extent degrade marriage. The declaration emphasizes that in the Orthodox tradition "monastic celibacy, moreover, implies no denigration of the sexual union proper to married life." (FLW: art. 27). Such extreme statement is urgent since contrary statements are common, especially in the days of the activation of Eschatological expectations. The declaration emphasizes the deep inner kinship of marriage and monasticism. Namely, both marriage and monastic life require deep self-sacrifice from the individual. The ethics of accepting the other, on which the Eucharistic way of life in marriage and monasticism is based, is complemented by the ethics of living for the sake of the other. But marriage also has the advantage that it becomes a way of coexisting with another as one being.

Marriage love as the fullest personalistic love serves to have own fruits. First of all, we are talking about childbirth, but not only about it. "Parenthood is a distinctively privileged symbol of love's transfiguring power, as well as of God's love for his creatures. Moreover, the blessing of children brings with it the vocation of the family as a whole to create a kind of polity, a microcosm emblematic of a redeemed creation, and therefore also a place of hospitality for those outside its immediate circle. Moreover, while true love is always fruitful, this fruitfulness is not only expressed through children; it can also be manifested through the diverse gifts of the Spirit: through hospitality, through service, and through common creative efforts of countless kinds" (FLW: art. 23). As we can see, social doctrine completely breaks with outdated notions that childbearing is the sole purpose of Christian marriage. Forming an ethics of acceptance in Christian communities of families who choose childlessness is an important task today in an increasing number of countries. If traditionalists do not want to see the family as a quantitative reality, social 
doctrine draws attention to the qualitative completeness, which can be varied. Alongside, the declaration emphasized the following: "The Church anticipates, of course, that most marriages will be open to conception; but she also understands that there are situations in which spiritual, physical, psychological, or financial impediments arise that make it wise - at least, for a time - to delay or forego the bearing of children" (FLW: art. 24). Thus, the Ecumenical Patriarchate has more liberal views on the regulation of childbearing than the Catholic Church. But at the same time for the social doctrine of the Ecumenical Patriarchate the sublime idea of sexual relations as a special expression of personal existence is distinctive. "Marriage is the sacrament of love, or human love raised into the world of the sacramental. It is the only sacrament that involves two persons freely and equally bound one to the other by God. Mystically, man and woman, husband and wife, become one, as the rite of matrimony says: "Yoke them in oneness of mind; crown them into one flesh." The Church took the institution of marriage - which had previously been a relationship understood largely in proprietary and legal terms, concerned principally with domestic and familial economy - and transfigured it into an indissoluble bond between persons that mystically signifies the love of Christ for his Church." (FLW: art. 20). Although the family is a model for all communities, marital unity is special, one that does not exist in other communities. Thus, the anthropological vocation to love is twice in a special way carried out in human life: first, in a relationship with God, where the fullness of love is possible, and second, in a marriage, when the deepest relationship is between two people who exist for each other. Like a relationship with God, a family relationship is open to giving love to others to change the reality of the world around us.

Of particular importance are Orthodox families in which one family member is non-Orthodox (FLW: art. 21). If there has been a tradition of different attitudes towards such marriages, the declaration emphasizes the contribution of these families to the transformation of the world around them (lbid).

The Declaration analyzes in detail the monastic life as a manifestation of love, while love for humanity is manifested in the monasticism of individuals and in monastic communities (FLW: art. 27). The monastic community is a "special exercise in love", forgiveness, gratitude, sacrifice (FLW: art. 27).

The document "For the Life of the World" also recognizes the existence of singles as an independent, third way of life today. "A third path of life, that of the adult who neither marries nor becomes a monastic, is sometimes a consciously chosen path, taken for any number of reasons particular to the individual, but at other times is a matter of mere circumstance. Certain persons are neither called to the monastic life, nor able or inclined to find a spouse. Such persons, however, are no less a part of the whole family of Christ's body, and no less able to contribute to the world's sanctification." (FLW: art. 28). The declaration especially emphasizes that single people have their own spiritual gifts that can enrich church communities. The equality of all the faithful, whichever way they choose (marriage, monasticism, solitary life) is proclaimed clearly and unconditionally. (FLW: art. 28-29).

Also, declaration separately declares respect for women, the inadmissibility of their humiliation due to outdated prejudices about ritual impurity (FLW: art. 29).
The role and rights of women are increasingly expanding in the churches, and the document "For the Life of the World" states: "The Church must also remain attentive to the promptings of the Spirit in regard to the ministry of women, especially in our time, when many of the most crucial offices of ecclesial life - theologians, seminary professors, canonists, readers, choir directors, and experts in any number of professions that benefit the community of faith - are occupied by women in increasingly great numbers; and the Church must continue to consider how women can best participate in building up the body of Christ, including a renewal of the order of the female diaconate for today" (FLW: art. 29). As we know, today the rank of the female diaconate exists in the Patriarchate of Alexandria, and in an incomplete format. Insisting on the possibility of its renewal in the Constantinopolitan Patriarchate and other local churches is a feature of major changes in the attitude to women. Increasing the subjectivity of women in church communities is an objective historical process, but not every church in its social doctrine has the courage to directly emphasize the irreversibility of this process and draw the necessary conclusions.

Respect for the individual must also be manifested in the right to a decent old age, natural death, which would not be caused by euthanasia applied for economic or social reasons (FLW: art. 30). Respect for the individual also encourages in the declaration to a radical statement that the church should accompany the funeral with its own prayers, even suicides (Ibid). Thus, we see in the document "For the Life of the World" the consistent Christian humanism upholding the principles of the absolute value of a person, his or her mental and bodily life, freedom, communication, identity.

\section{Conclusions}

The image of the family in the declaration "For the Life of the World" shows that today the family cannot be a model for any other society. Firstly, the family is not an independent reality, but is rooted in an interpersonal relationship with God. From these relationships, family members receive all the gifts that generally distinguish families or should distinguish them. Secondly, the family is not an absolute value which persons are subordinate to. On the contrary, the family is a space for the manifestation of personality, just as equal possible scenarios of selfrealization are monasticism and a solitary way of life. Invariable at all set of possible life scenarios, the statement of ontological value of communication for the person remains. This communication is most fully realized between a man and a woman, but other types of communication are also important for the constitution of the individual. Thus, deep real interpersonal relationships, not necessarily related to the institution of the family, become a model for any society. Standards with regard to the family life are substantially mitigated which is the manifestation of trends to the constant humanization of the social teaching of the Orthodox Church. Such humanization is natural not only because of the influence of historical circumstances, but also because of the disclosure of the inner potential of Christian personalism. Such mitigation of norms regarding the family life, sexuality, and the church's attitude to various life circumstances does not lead to the relativization of the ideal of the sanctity of family life. This is ensured mainly by emphasizing the sanctity of true interpersonal relationships. 


\begin{tabular}{l|r||r}
\hline 60 & Релігієзнавство \\
\hline
\end{tabular}

\section{REFERENCES}

Chryssavgis, J.\& Hollander, A. (2020, November 24). Asceticism, Ethics, and the Renewal of the Earth: Orthodox Christian Contributions to an Ecumenical Ecology. Franciscan Friars of the Atonement. Retrieved from https://www.atonementfriars.org/asceticism-ethics-and-the-renewal-of-the-earth/.

Frost, C.F. (2020). 'The Orthodox Church and Its Social Ethos: The Aims and Accomplishments of For the Life of the World', Ecumenical Trends, 49 (5). Graymoor Ecumenical \& Interreligious Institute. September/October: 1-6. Retrieved from https://panorthodoxsynod.blogspot.com/2020/10/theorthodox-church-and-its-social.html

Greek Orthodox Archdiocese of America, Ecumenical Patriarchate (2020). For the Life of the World. Toward a Social Ethos of the Orthodox Church. University of Fribourg. Retrieved from https://www.unifr.ch/orthodoxia/en/news/news/24780/for-the-life-of-the-worldtoward-a-social-ethos-of-the-orthodox-churchtranslated-into-german-by-barbara-hallensleben?

His Grace Bishop Maxim \& Fr. John Chryssavgis (2020). Join the Conversation: For the Life of the World. A New Document in the Church. Retrieved from https://youtu.be/yZULvc4MaWA

Dr. Brandon Gallaher \& Dr. Phil Dorroll (2020). Join the Conversation: For the Life of the World. Ecumenical and Interfaith Relations. Retrieved from https://youtu.be/7MOTr7kCtlk .

Dr. Carrie Frederick Frost \& Dr. Philip Mamalakis (2020). Join the Conversation: For the Life of the World. Marriage and Family. Retrieved from https://youtu.be/XXkNkcDiVFw

Fr. Nicolas Kazarian \& Dr. Elizabetha Kitanovic (2021). Join the Conversation: For the Life of the World. Orthodoxy and Human Rights. Retrieved from https://youtu.be/iWELWMGZu38.

Dr. George Demacopoulos \& Fr. Martin Johnson (2020). Join the Conversation: For the Life of the World. Poverty and Wealth. Retrieved from https://youtu.be/ZDNWUgc6c5I.

Dr. Gayle Woloschak \& Dr. Tim Patitsas (2020). Join the Conversation: For the Life of the World. Religion and Science. Retrieved from https://youtu.be/5cA7TGdbmP8.

Dr. Aristotle Papanikolaou \& Hank Hanegraaff (2020). Join the Conversation: For the Life of the World. Religion and the Public Square. Retrieved from https://youtu.be/kjnGM-m6DC4.

Fr. Perry Hamalis \& Fr. Demetrios Harper (2020). Join the Conversation: For the Life of the World. War and Peace. Retrieved from https://youtu.be/OvcL9UA40Hs.

Богдан Гулямов,

Національний педагогічний університет імені М. П. Драгоманова (м. Київ, Украӥна)

e-mail: b.s.gulyamov1970@gmail.com, ORCID 0000-0001-8523-5420

\section{СОЦІАЛЬНЕ ВЧЕННЯ ВСЕЛЕНСЬКОГО ПАТРІАРХАТУ ПРО РОДИНУ}

Вчення про родину стоїть у центрі класичної християнської соціальної доктрини, оскільки родина є взірцем для всякої соціальності - церковної громади, трудового колективу, місцевої громади, нації, людства. Сучасна криза родини приводить до трансформації соціального вчення, коли взірцем стають міжособистісні відносини. А саме, відносини між чоловіком та жінкою в родині, відносини особистості та Бога, відносини у чернечій громаді, відносини у церковній євхаристійній громаді стають загальним ідеалом, який пропонується для світської соціальності. У етиці родинного життя соціальне вчення Константинопольського патріархату особливий наголос робить на абсолютній гідності особистості від моменту їі зачаття до природної смерті. Велика увага приділяється захисту дітей від різноманітних загроз у соціумі, пропонуються дієві заходи для уникнення злочинів проти дітей. Також дається апологія усіх сторін сексуального життя родини, засуджуються різноманітні упередження щодо жінок та шлюбу. В цілому соціальне вчення Константинопольського патріархату про родину є виразом етики християнського реалізму, при якому визнання абсолютності певних цінностей поєднується з готовністю зрозуміти і простити людські помилки. У вченні про родину соціальне вчення 3 позицій комунітаризму переходить до прийняття засад християнського персоналізму.

Ключові слова: соціальне вчення; православна традиція; християнський персоналізм; теологія любові.

(c) Bogdan Gulyamov

Надійшла до редакції: 10.12.2020

Прийнята до друку: 08.02.2021 